\title{
Did RESIDENTIAL ELECTRICITY RATES FALL AfTER RETAIL COMPETITION? A Dynamic Panel ANalysis
}

\author{
MINE YÜCEL AND ADAM SWADLEY \\ RESEARCH DEPARTMENT \\ WORKING PAPER 1105
}

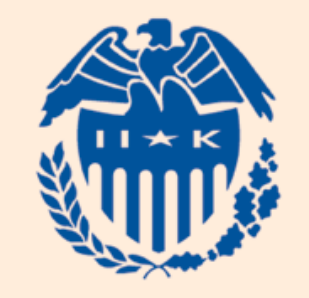

Federal Reserve Bank of Dallas 


\title{
Did Residential Electricity Rates Fall After Retail Competition?*
}

\section{A Dynamic Panel Analysis}

May 2011

Adam Swadley and Mine Yücel

Federal Reserve Bank of Dallas

\begin{abstract}
A key selling point for the restructuring of electricity markets was the promise of lower prices, that competition among independent power suppliers would lower electricity prices to retail customers. There is not much consensus in earlier studies on the effects of electricity deregulation, particularly for residential customers. Part of the reason for not finding a consistent link with deregulation and lower prices was that the removal of the transitional price caps led to higher prices. In addition, the timing of the removal of price caps coincided with rising fuel prices, which were passed on to consumers in a competitive market. Using a dynamic panel model, we analyze the effect of participation rates, fuel costs, market size, a rate cap and a switch to competition for 16 states and the District of Columbia. We find that an increase in participation rates, price controls, a larger market, and high shares of hydro in electricity generation lower retail prices, while increases in natural gas and coal prices increase rates. The effects of a competitive retail electricity market are mixed across states, but generally appear to lower prices in states with high participation and raise prices in states that have little customer participation.
\end{abstract}

\footnotetext{
* The views expressed are those of the authors and are not necessarily those of the Federal Reserve Bank of Dallas or the Federal Reserve System. The authors thank Anil Kumar for helpful comments, as well as seminar participants at Rice University for helpful comments on an earlier draft.
} 


\section{Did Residential Rates Fall After Retail Competition? A Dynamic Panel Analysis}

\section{Introduction}

Electricity market restructuring has received significant attention in the energy economics literature, particularly in the mid-2000s after many states restructured their electricity markets and offered retail choice. A key selling point for the restructuring of electricity markets was the promise of lower retail electric prices, that competition among independent power suppliers to lure customers from the incumbent utility company's default or "standard offer" service would lower prices to retail customers.

There is no consensus among earlier studies on how restructuring affected retail prices. Zarnikau and Whitworth (2006), Rose (2004) and Joskow (2006) note that large commercial and industrial customers have realized some cost-saving benefits from competition, while Apt (2005) concludes that competition has not lowered electricity rates for industrial users. Joskow (2006) finds retail competition lowers both residential and industrial electricity prices, but attributes the price decline to non-market artifacts of restructuring legislation and regulated default service rather than competitive forces. In a study focusing on the residential market in Texas, Zarnikau and Whitworth (2006) show that electricity rates rose faster in areas of the state that were open to retail competition than in areas that were not.

It is important to note that the timing of many of these earlier studies of electricity restructuring was such that many of the states offering retail choice to residential customers had regulated default service, transitional pricing mechanisms, or other price controls in place. These temporary price controls varied across states, but their common purpose was to protect consumers and power generators from price volatility in the transition to a competitive market. As Joskow (2006) notes, there is an inseparability of the effects of these price controls from 
those of increased competition, resulting in overstated benefits of retail competition. Further, as Axelrod, et.al. (2006) point out, the expiration of these price controls led to sharp rate increases as price controls were removed and market forces took over. Another factor in the rise of retail price was that the expiration of many of these price controls was followed by periods of fuel cost increases. Together, these factors contributed significantly to higher electric rates and led many to conclude that competition at the wholesale and retail levels had resulted in higher electric rates (Axelrod, DeRamus, and Cain, 2006). In a more recent paper, Kang and Zarnikau (2009) show that retail prices declined in Texas after the removal of price caps.

The Electric Reliability Council of Texas (ERCOT) market presents an especially interesting case for study and a baseline for comparison given its wide regard as the most successful retail market in North America (Adib and Zarnikau, 2006). The ERCOT market has been successful in attracting a large number of providers offering choice to customers of all sizes. The ERCOT market also leads all other states with $50.6 \%$ of residential customers choosing a competitive retail electric provider $(\mathrm{CREP})^{1}$. In this paper, we use panel data to study 16 states and the District of Columbia that started retail competition in the late 90s and early 2000s, and have mainly completed their restructuring and ended their transitional prices. Among these states, only California and Virginia have suspended retail competition for residential customers. Given that transitional pricing ended several years ago in most of these states, we have several years of data to study the effects of retail competition. We contribute to the literature in a couple of ways. We estimate the effects of retail competition and transitional pricing on residential electric rates, using Texas as a baseline and estimating separate effects of these policies for individual states in our panel where possible. The second major contribution of

\footnotetext{
${ }^{1}$ As of May 2010. Percent of eligible ERCOT area residential customers who have chosen a competitive retail electric provider.
} 
this paper is to estimate the effect of increased residential customer participation in a competitive markets on residential electric rates. The analysis is conducted using a dynamic panel model, where cost drivers and participation are allowed to affect residential electric rates with a lag. We find that an increase in participation rates, price controls, a larger market, and high shares of hydro in electricity generation lower retail prices, while increases in natural gas and coal prices increase rates. The effect of moving to a competitive retail electricity market is mixed across states, but generally appears to lower prices in states with high participation and raise prices in states that have little customer participation.

\section{Data and Model}

Our goal is to develop a model of electricity prices for residential customers that takes advantage of differences both within and across states that have or have had retail competition in their electricity markets. We are interested in examining differences in the effects of retail competition programs and transitional pricing schemes across states. Earlier studies (eg, Joskow 2006) do a panel data analysis of a similar flavor but do not attempt to single out differences across states. Further, earlier studies fail to separate the effects of retail competition from temporary effects of transitional price controls and level of participation by residential customers. We develop a dynamic panel model that accounts for the aforementioned issues.

The data employed in our analysis is a monthly panel of 16 states and the District of Columbia. The states analyzed are CA, CT, DC, DE ,IL, MA, MD, ME, MI, NH, NJ, NY, OH, PA, RI,TX and VA. Table 1 shows these states and the start and completion of their restructuring. The panel contains 3,247 observations and covers a period from January 1990 to May 2010. The data are primarily from the U.S. Energy Information Administration (EIA) and state Public Utility Commissions. The dependent variable is seasonally adjusted average real price per kilowatt-hour $(\mathrm{kWh})$ for residential customers. As a key independent variable, we 
include the percent of eligible residential customers who have chosen a competitive provider in each state to capture the level of market participation by residential customers. The model allows participation by residential customers and various control variables to affect residential electric rates at a lag of up to six months. We choose the six month lag length as suggested by the Energy Information Administration (EIA, 2007), because fuel costs would take around six months to be reflected in customer rates. We use this lag length as a base for our model and assume that other cost drivers would take an equal or lesser amount of time to be reflected in customer rates.

To control for input costs of electric generating facilities that might be passed on to customers, we include the real average cost of coal for electricity generation and the real average cost of natural gas for electricity generation. We also include controls for each state's percentage of generation from nuclear and hydro sources. The total number of megawatt hours sold in each state is included to control for market size, and the deviation from normal heating and cooling degree days is included to capture weather-related demand spikes. We include dummy variables to capture months when each state is open to electric competition for residential customers ${ }^{2}$, and months when each state had some sort of price control or transitional pricing (rate cap, rate freeze, etc.) in addition to retail competition. Finally, we include a lag of seasonally adjusted average real price per kilowatt-hour $(\mathrm{kWh})$ for residential customers in an effort to proxy for unknown omitted variables that affect prices historically. This lagged dependent variable may also partially pick up fixed pricing schemes offered to customers.

\footnotetext{
${ }^{2}$ While many states had "pilot" periods where some portion of residential customers were able to choose their electric provider, the retail competition dummy variable is set $=1$ only when retail competition is open to ALL residential customers. The exception here is Texas, where we make the simplifying assumption that all residential customers are eligible to choose their provider. In fact, only about $85 \%$ of the Texas residential market is open to competition.
} 


\section{Estimation}

The baseline model to be estimated is of the form:

$$
\Delta y_{i t}=\left(\Delta \mathbf{x}_{i, t-k}\right)^{\prime} \boldsymbol{\beta}+\delta\left(\Delta y_{i, t-1}\right)+\mathbf{f}_{i t}{ }^{\prime} \boldsymbol{\gamma}+\Delta \boldsymbol{\varepsilon}_{i t}
$$

where $\mathbf{x}$ is a vector of control variables at lags $k \in \mathrm{K}=\{0,1,2,3,4,5,6\}$ believed to influence residential electric rates:

PARTICIPATION ${ }_{i, t-k}$

LNTOTALSALESMWH $H_{i, t-k}$

LNCOALPRICEELECGEN $N_{i, t-k}$

LNGASPRICELECGEN $N_{i, t-k}$

PCNTHYDRO $_{i, t-k}$

PCNTNUCLEAR $R_{i, t-k}$

$C D D E V_{i, t-k}$

$H D D E V_{i, t-k}$
Percent of residential electric customers in state $i$ choosing a competitive retail electric provider at time $t-k$

Log of total megawatt hours sold in state $i$ at time $t-k$ Log of real national average cost of coal for electricity generation at time $t-k$

Log of real national average cost of natural gas for electricity generation at time $t-k$ Percent of electric generation from hydro in state $i$ at time $t-k$

Percent of electric generation from nuclear in state $i$ at time $t-k$

Deviation from normal number of cooling degree days in state $i$ at time $t-k$ Deviation from normal number of heating degree days in state $i$ at time $t-k$

and $\mathbf{f}$ is a vector of dummy variables:

RETAILCOMP $P_{i t} \quad=1$ if state $i$ was open to residential retail electric competition at time $t ;=0$ otherwise

RATECAP $_{i t} \quad=1$ if state $i$ had a transitional price control or rate cap in place at time $t ;=0$ otherwise

RETAILCOMP $_{i t} *$ STATE $_{i}$ Interaction of STATE $E_{i}$ with RETAILCOMP Rt, $_{\text {, defined above }}{ }^{3}$

RATECAP $_{i t}{ }^{*}$ STATE $_{i} \quad$ Interaction of STATE $i$ with RATECAP $i t$, defined above

\footnotetext{
${ }^{3}$ This allows for estimation of a state-specific coefficient for RETAILCOMP that is used to determine the effects of retail competition in that state particular state. The RATECAP and the state dummy variable interaction serves an analogous purpose. Texas is the omitted state dummy and serves as the baseline for comparison.
} 
We first-difference all continuous variables to remove fixed effects that maybe present while also addressing nonstationarity of the individual time series. Dummy variables controlling for retail competition and transitional pricing schemes enter the model in levels. We adopt the level form of the dummy variables to capture effects on residential electricity rates over the time they are in place rather through a one-time impact ${ }^{4}$.

The introduction of a lagged dependent variable as a regressor in the framework of a usual first-differences model results in inconsistent estimates because of correlation between $\Delta y_{i, t-1 \text { and }} \Delta \boldsymbol{\varepsilon}_{i t}$, through the shared term $\boldsymbol{\varepsilon}_{i t-1 .}$ Several techniques have been suggested to handle such situations. Anderson and Hsiao (1982) suggest using an instrumental variables approach to estimate a first-differenced equation, where the lagged dependent variable regressor $\left(\Delta y_{i, t-1}\right)$ is instrumented using either $\Delta y_{i, t-2}$ or $y_{i, t-2}$. Arellano (1989) finds efficiency in the approach of using the level variable as an instrument in lieu of lagged differences, and Arellano and Bond (1991) examine one-step and two-step GMM estimators that essentially expand on the work of Anderson-Hsiao (1982) and Holtz-Eakin, Newey, and Rosen (1988). The Arellano-Bond (1991) approach considers additional lags of the dependent variable as instruments, thus improving efficiency by taking advantage of the additional moment conditions. Kiviet (1995) proposes the usual least squares dummy variable approach and develops a bias correction that he finds to be more efficient than GMM estimates.

We face an additional complication in choosing an appropriate estimation technique because we have a long panel, i.e., a long time dimension (large T) and few cross sections (small $\mathrm{N}$ ) while all of the aforementioned solutions assume large $\mathrm{N}$ and small $\mathrm{T}$. Judson and Owen (1999) address this very topic, conducting a Monte Carlo study to examine the properties of

\footnotetext{
${ }^{4}$ This is a simplifying assumption. Idiosyncrasies across states will result in price controls and retail competition affecting prices over varied time periods.
} 
these estimators in our situation and that usually faced by macroeconomists. Judson and Owen (1999) conclude that even with a fairly long time series, the asymptotic bias should not be ignored, although they do find improvement in all estimators as the time dimension of the panel increases. The suggested method for the longest timeframe considered with an unbalanced panel is the usual least squares dummy variable fixed effects estimator (Judson and Owen, 1999). This is consistent with the findings of Nickell (1981) and the suggestion of Roodman (2006). We also consider Judson and Owen's (1999) suggestion of Arellano-Bond one-step GMM estimation as a second best choice. Because Arellano-Bond estimation is an instrumental variables approach, it has the added advantage of allowing us to test for and address, if necessary, potentially endogenous variables in the model such as PARTICIPATION.

Due to the possibility of endogeneity of the PARTICIPATION variable, as well as to mitigate any concerns of inconsistency or concerns of spurious correlation resulting from nonstationarity of individual time series, we settle on Arellano-Bond one-step difference GMM estimation. A difference-in-Sargan test suggests that in fact, the PARTICIPATION variable is not endogenous in this data and therefore does not need to be instrumented. We believe this finding is plausible given the length of the time series employed and that in this particular data set, well over half of the years in the set contain PARTICIPATION values of zero yet some price fluctuation still occurred. We proceed in our analysis operating under this assumption.

Because the time dimension of our panel is large, we must be aware of the issue of instrument proliferation resulting from Arellano-Bond estimation on data with a large time dimension. Using the default Arellano-Bond approach in panels with long time dimensions, the number of instruments grows rapidly and causes overfitting of the endogenous variables (Cameron and Trivedi, 2010; Roodman, 2006). Roodman (2009) suggests two solutions to this problem. The first is limiting the number of lags to be used as instruments to fewer than all 
available lags as is the default of Arellano-Bond. This results in what Judson and Owen (1999) call a "restricted GMM" estimator, which they find to be computationally less-taxing but without significant loss of effectiveness. Additionally, Roodman (2009) suggests “collapsing” the instrument matrix. This involves horizontally collapsing the usual instrument matrix containing an instrument for every lag available at each time period (a matrix that is quadratic in $\mathrm{T}$ ) to a simplified instrument matrix that only adds columns or instruments when additional lags are used as instruments. The moment conditions associated with the usual instrument matrix imply the moment conditions associated with the collapsed instrument matrix, however, some efficiency is lost simply because there are fewer moment conditions to satisfy.

We employ both of Roodman's (2009) suggestions for reducing the instrument count. Keeping with a goal of a few, strong instruments we choose to limit our set of instruments to two lags of the dependent variable; specifically, instruments for $\Delta y_{i, t-1}$ are $y_{i, t-2}, y_{i, t-3}$. This allows efficiency gains over the just-identified case while still keeping the size of the instrument matrix under control. Estimation with three lags as instruments results in no observable efficiency gains, and more than three lags cannot be confirmed as valid instruments ${ }^{5}$. As a check of robustness and to increase the model's flexibility, we also consider an analogous model with the addition of year time dummies.

We estimate both models with the intention of examining contemporaneous and lagged effects. The contemporaneous effect is determined from the coefficient at lag 0 . To determine lagged effects of our control variables, we perform hypothesis testing on sums of lagged coefficients. This allows us to determine the number of months over which the variable has a lagged impact on residential electricity rates.

\footnotetext{
${ }^{5}$ As suggested by the Arellano-Bond test for AR(2) in first differences when more than three lags are used as instruments.
} 


\section{Results}

The results from the estimation are generally consistent with our expectations. Tables $3 \mathrm{a}$ and $3 \mathrm{~b}$ show results from the baseline model. An increase in participation rates takes some time to be reflected in lower electricity prices. Although the contemporaneous effect of the participation rate on retail prices is positive and significant, the lagged effects of increased participation are negative, significant, and larger in magnitude than the contemporaneous effect. A 10 percentage point increase in participation initially raises the price by 2.9 percent but then lowers the price by 4.3 percent, with the full effect taking around 6 months to be reflected in prices. The positive coefficient estimate on the contemporaneous effect of increased participation matches Kang and Zarnikau's (2009) results. A higher participation rate implies that a larger group of residential customers are switching to competitive retail electricity providers (CREPs), increasing the share supplied by competitive retailers, and eventually lowering the overall residential price of electricity. The magnitude of the coefficient may seem small, but it is similar to estimates by Kang and Zarnikau (2009) for Texas. As Chart 1 shows, the participation rate does not start rising for some states until the states are well into restructuring, and really takes off after price controls are removed. In the case of Texas, participation rises nearly linearly from the start of retail competition, suggesting a transitional pricing scheme that encouraged competition early on. These differences illustrate the idiosyncrasies of state transitional pricing schemes that provide different incentives for customers to switch providers, and for competitive providers to serve residential customers in a given market. These differences and findings are further discussed below. For many states, participation rates are still quite low, but our findings suggest that higher participation rates lead to lower retail prices. 
The contemporaneous effect of a change in total megawatt hours sold in a state is a statistically significant decline in retail prices. Lagged effects are positive but statistically insignificant. If we think of the MWh variable as a measure of the size of the total electricity market, then the larger the market, the more suppliers it can support, leading to more competition and lower prices. A larger market may also result in lower prices because of economies of scale in electricity generation.

As would be expected, increases in the prices of fuels used to generate electricity have an overall positive effect on retail prices. The effects of the rise in fuel prices come in with a lag, as neither coal nor natural gas prices used in electricity generation have a significant contemporaneous effect on retail electricity prices. A rise in natural gas prices has a significant effect on electricity prices with a lag of two months, reflecting the time required for increased fuel costs to be passed to consumers. As seen in Table 3a, a 10 percent increase in the price of natural gas leads to a statistically significant 0.2 percent increase in the price of electricity at the end of two months. To put this in perspective, if an average customer used $1000 \mathrm{KWh}$ per month, a 10 percent increase in natural gas prices would imply a small $\$ 3.29$ increase in the customer's annual electricity bill, assuming the panel mean rate of 13.7 cents/KWh. In the first half of our sample, natural gas prices to electricity generators were relatively stable, averaging around $\$ 2.50$ per year. Furthermore, electricity rates in the vast majority of states were still under regulation and less sensitive to short run volatility in fuel prices. However, in the second half, as restructuring got under way in the 2000 s, natural gas prices were very volatile (Chart 2), with prices ranging from $\$ 4$ to $\$ 12$. As rate caps ended, consumers who had switched to competitive providers and who were in states which depended on natural gas for a majority of their generation, such as Massachusetts, Maine, New York, and Texas probably saw their retail prices go up substantially as natural gas prices remained high. However, our finding of a relatively 
small effect of natural gas prices on monthly retail rates is consistent with Bushnell and Mansur's (2005) finding that monthly retail rates do not capture much of the volatility of natural gas prices. Moreover, most generators buy their natural gas with longer contracts, rather than on the spot market, dampening the pass-through of short-term gas price volatility.

Similarly, an increase in the price of coal has a positive and significant effect for all lags. A10 percent increase in the price of coal results in increases in retail electricity prices ranging from 2.1 percent in the first month to 2.9 percent through the sixth month. This effect is much larger than the effect of gas prices; however, coal prices have been much less volatile over the sample period.

For states that used either hydro or nuclear as the energy source for electricity generation, an increased share of hydro generation lowers retail prices while an increased share of nuclear generation has no significant effect on retail prices because all nuclear coefficients are all insignificant. No state in our panel has hydro as their main source of generation, but California, New York, and Maine all have a sizable hydro share. Nuclear is the main source of energy for Connecticut's electricity generation, while Illinois has 48 percent, New York has 31 percent and Pennsylvania has a 35 percent share of nuclear in their power generation. Comparing our results to Joskow (2006), we find that signs on our contemporaneous coefficients (which are insignificant) are opposite of Joskow's but that our lagged effects match the sign of Joskow's results. Two points are worth noting here. First, Joskow (2006) uses annual rather than monthly data. Second, because we are dealing with monthly data we are primarily interested in the lagged effects of these variables since changes in generation costs take some number of months to be reflected in customer rates. Thus, it seems plausible that signs on our lagged values using monthly data would more closely match Joskow’s (2006) contemporaneous values using annual data. 
We would expect deviations from normal heating and cooling degree days to have a positive effect on retail prices. The signs of the coefficients of these variables are mixed, but all were insignificant, adding no explanatory power to the estimation. One possible explanation for these results could be that the effect of these variables is being picked up by the electricity usage variable.

Table $3 \mathrm{a}$ also shows the state effects of retail competition and transitional pricing (the RETAILCOMP and RATECAP variables) on retail prices. The separate state dummy variables for RETAILCOMP and RATECAP are useful for two reasons. First, states have had varied levels of success in their restructuring efforts. Second, it is likely that the timing of effects from different retail competition setups and price controls was quite different. For instance, one state may have seen the full effect as soon as a price control was put in place while a different state may have seen more gradual price effects. The coefficients on the RETAILCOMP and RATECAP dummies are interpreted as the monthly growth of residential electricity rates when retail competition and/or a price control is in place. These coefficients are best interpreted if annualized. Annualizing the coefficient -.0034 for RETAILCOMP suggests that, holding all else equal, having a competitive retail market in Texas caused the average residential electric bill to decline at approximately a 4.0 percent annual rate over the sample period.

Our results suggest that state effects of competitive markets and transitional pricing are somewhat mixed. For Texas, Connecticut, Maine, and Pennsylvania, moving to a competitive retail market lowers retail prices. Texas, Connecticut, and Pennsylvania have relatively high participation rates, and Pennsylvania still had some price controls in place over our sample period. Although the participation rate for Maine is low in Table 1, Maine's restructuring initiatives differ from many other states and a very high percentage of Maine customers essentially get their power through a competitive market. The incentive for Mainers to choose a 
competitive retail provider is limited because Maine's standard offer service generation is already procured through a competitive bidding process. This keeps prices low and eliminates both the incentive for residential customers to choose a different provider and for competitive retail providers to serve residential customers in that market. The coefficient for Maine is negative and statistically significant suggesting that Maine's unique style of competition, although not dependent on individual customers, may also be effective in lowering retail prices.

For the remaining states, the switch to retail competition did not necessarily lower retail prices. For CA, DE, IL, MD, MI, NJ, and DC, having a competitive market actually appears to have raised rates while MA and NY have statistically insignificant coefficients, implying no change in retail prices in these states. It is possible that the participation rate, which starts rising after transitional pricing is eliminated, is picking up much of the effect of restructuring, as would be expected if price decreases are driven by competitive forces. The significant (and largely positive) coefficients on retail competition in states with relatively low participation suggest that higher rates of participation in the retail market are necessary to successfully lower residential electric rates.

Looking at the effects of price controls on state retail prices, the results for all states except for Massachusetts are significant. For Texas, price controls increased retail prices, a finding that agrees with Kang and Zarnikau (2009). This is likely a function of the design of the "price-to-beat" in Texas, which was held relatively high to encourage competitive providers to enter the market and to encourage customer switching to competitive retailers. For the rest of the states, rate caps had a significant effect in lowering retail electricity prices.

As a check of robustness and for added model flexibility, we estimated an additional model, adding time dummies to the baseline model. Tables $4 \mathrm{a}, 4 \mathrm{~b}$, and $4 \mathrm{c}$ show that the basic 
results do not change when time dummies are added. Both the participation and total megawatt hours variables become more significant and their coefficients increase slightly. Most notably, the coefficients on retail competition in MI and NJ lose significance, while the coefficients on retail competition for MA and NY become negative, implying a fall in retail prices with competition, although the coefficients remain insignificant. The addition of time dummies has almost no effect on the RATECAP variables, with the exception of the price control variable becoming significant for MA. The time dummies themselves are insignificant 16 out of the 20 years (table 4c). Interestingly, the coefficients for the time dummies are mostly positive in the first half of the sample period and negative in the latter half. Although these coefficients are not statistically significant, the negative signs suggest some overall downward movement of retail

prices over the period. This could suggest that the time dummies in these periods are picking up, to some degree, the effects of national level wholesale deregulation initiatives around this time, as well as newly restructured wholesale markets overseen by regional transmission operators and independent system operators.

\section{Discussion}

The recent expiration of transitional price controls in many states' competitive electricity markets has provided us with a data set that allows us to shed light on whether a truly competitive retail market lowers rates for residential customers. Our results strongly suggest that if such a market is designed correctly, residential customers may benefit from competition among electricity providers. Although the level of benefit may vary, evidence also suggests that there is no single correct way to implement a successful competitive retail market, as demonstrated by the successes of states with very different approaches (Maine and Texas, for example). 
Our results show that none of the retail electricity market designs yield instant price reductions for customers. States that held prices artificially low during the transition to a competitive market may have seen lower prices initially; however, the long-run effect of artificially depressed prices is a misallocation of resources and an inefficient electricity market. Consumers have no incentive to switch to an alternative electricity provider and providers have no incentive to enter the market to serve residential customers. A successfully designed market must provide profit opportunities for providers as well as incentives for consumers to switch providers. Although this may result in higher-than-desired rates initially, in the long-run intensified competition is more to likely yield sustainable lower rates. An alternative seeminglysuccessful approach is to procure standard-offer electricity services through a competitive bidding process, as in Maine. This approach does not have the dependence on retail customers' participation, but still has the potential to yield some level of benefit resulting from competition.

Beyond simply reducing electricity rates, a competitive retail market holds the potential to achieve other policy goals through the workings of the marketplace. If increased generation from alternative fuels is a policy goal and there are consumers demanding electricity from alternate fuels, a competitive retail market can match these customers with their suppliers. As Roe et.al. (2001) note, an increased willingness to pay for electricity generated from renewable fuels suggests that a competitive retail market may be one step in achieving renewable energy goals.

It is also important to consider the impacts of new smart grid technologies and alternative rate structures on competitive retail electricity markets. Our results show that in the current environment, a robust competitive retail electricity market can offer lower average monthly electricity rates. As new technologies increase customer price awareness, rate structures such as time-of-use and real time pricing — pricing that more closely reflects fluctuations in the 
wholesale market—offer the potential for greater pricing transparency and even greater average monthly savings. However, in this environment retail electricity providers are no longer competing with an advertised monthly rate and may offer a wider variety of more complex rate plans. Such an environment would obviously benefit customers who have high demand elasticities or who have the highest demand during off-peak hours. Overall reductions in statelevel average monthly prices, as we show in this paper, are less clear. This is an area for future research as smart grid technologies become more widespread in mature competitive markets.

\section{Conclusion}

The restructuring of U.S. electricity markets has received a great deal of attention in the energy economics literature, particularly in the mid 2000s as many states experimented with retail competition. Earlier studies on the effects of restructuring initiatives have failed to reach a consensus, particularly as these initiatives apply to residential customers. Previous efforts to study this topic were complicated by an inseparability of the effects of temporary transitional pricing schemes from the true effects of a competitive market. With several years of data following the expiration of many of these temporary pricing schemes, we revisit this issue using an econometric approach unique to this literature. Increasing participation in the competitive market appears to be a crucial element in reducing residential electric rates, while price reductions detected by earlier studies were likely driven by price controls rather than competitive forces. With the exception of Maine's somewhat unique bid-for-generation setup, states that have failed to provide the proper market incentives for residential customers to switch to a competitive provider and for firms to provide electricity to residential customers have been less successful in reducing residential electric rates. Our findings suggest that with a market design that encourages adequate participation, a competitive retail electricity market can benefit residential customers. 


\section{Status of Electric Market Restructuring as of September 2010}

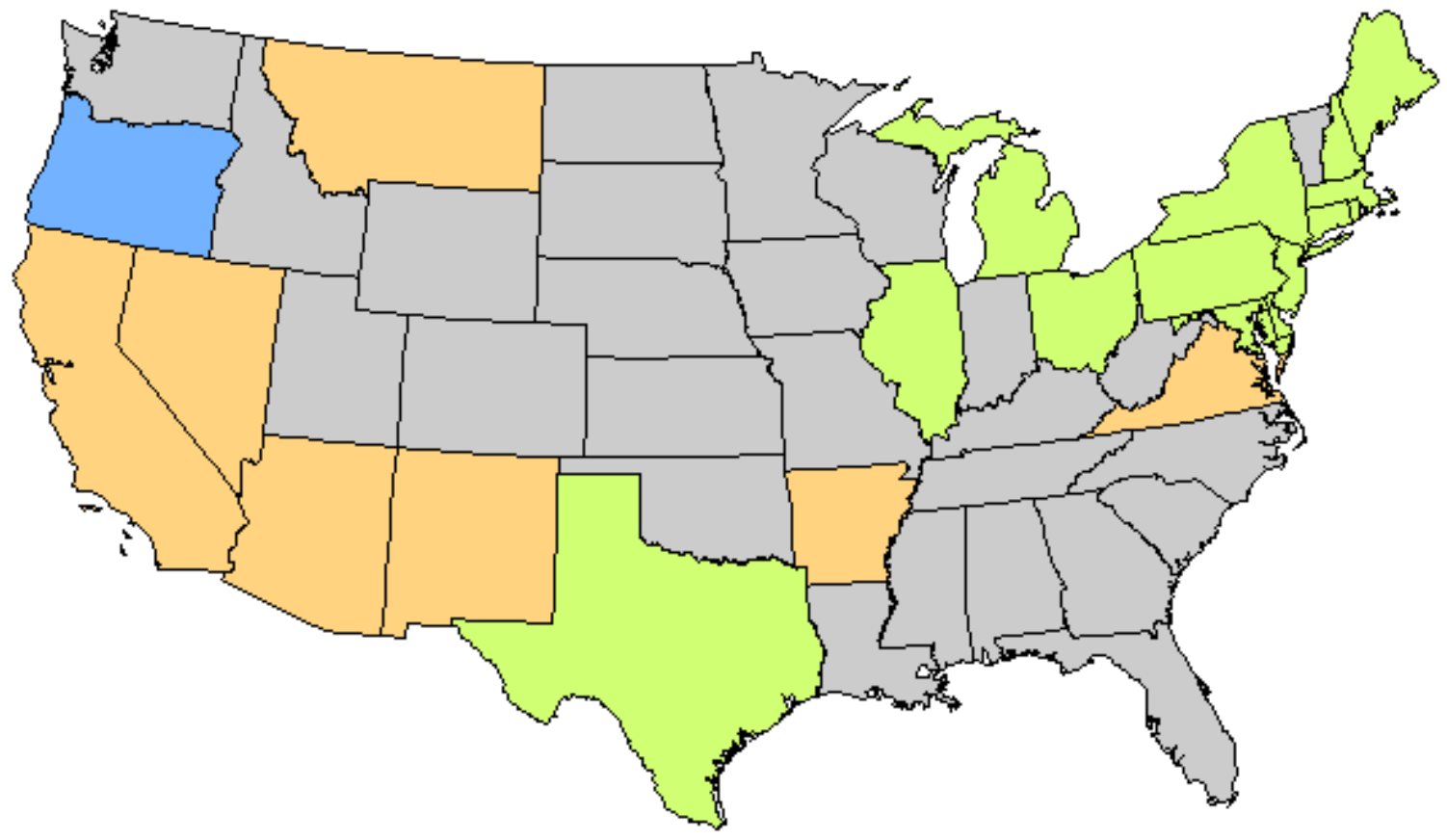

$\square$ No Restructuring

Restructuring Active- All Customers

Restructuring Suspended

Restructuring Active- No Retail Competition for Residential Customers 
Table 1. State Electricity Restructuring

\begin{tabular}{|c|c|c|c|c|c|}
\hline State & $\begin{array}{c}\text { Main Energy } \\
\text { Source }\end{array}$ & $\begin{array}{c}\text { Participation } \\
\text { Rate }\end{array}$ & $\begin{array}{c}\text { Retail Comp } \\
\text { Begin }\end{array}$ & $\begin{array}{c}\text { Rate Cap } \\
\text { Begin }\end{array}$ & Rate Cap End \\
\hline CA & Gas & $0.6 \%$ & \multicolumn{2}{|c|}{ Deregulation Suspended September 2001 } \\
\hline CT & Nuclear & $24.6 \%$ & July 2000 & July 2000 & January 2007 \\
\hline DC & Petroleum & $3.4 \%$ & January 2001 & January 2001 & February 2007 \\
\hline DE & Coal & $2.6 \%$ & October 2000 & October 2000 & May 2006 \\
\hline IL & Coal & $0.01 \%$ & May 2002 & August 1998 & January 2007 \\
\hline MA & Gas & $12.3 \%$ & March 1998 & March 1998 & March 2005 \\
\hline MD & Coal & $6.7 \%$ & July 2000 & July 2000 & June 2006 \\
\hline ME & Gas & $2.6 \%$ & March 2000 & N/A & N/A \\
\hline MI & Coal & $0.0 \%$ & January 2002 & January 2002 & January 2006 \\
\hline NH & Nuclear & N/A & July 1998 & July 1998 & May 2006 \\
\hline NJ & Nuclear & $0.5 \%$ & June 1999 & June 1999 & August 2003 \\
\hline NY & Gas & $17.9 \%$ & May 1999 & May 1999 & August2001 \\
\hline OH & Coal & $22 \%$ & January 2001 & January 2001 & --- \\
\hline PA & Coal & $11.3 \%$ & January 2000 & January 2000 & January 2011 \\
\hline RI & Gas & N/A & July 1998 & January 1998 & January 2004 \\
\hline TX & Gas & $50.6 \%$ & January 2002 & January 2002 & January 2007 \\
\hline Coal & N/A & Deregulation Suspended April 2007 \\
\hline
\end{tabular}


Table 2. State Electricity Generation by Source: 2008

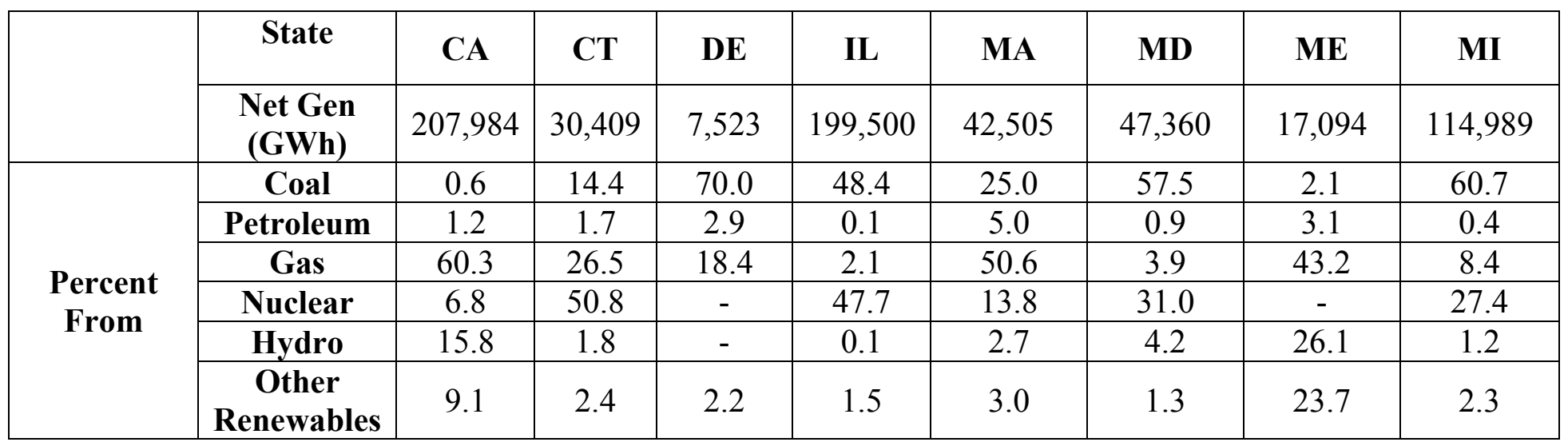

\begin{tabular}{|c|c|c|c|c|c|c|c|c|c|c|}
\hline & State & NH & NJ & NY & OH & PA & RI & TX & VA & DC \\
\cline { 2 - 12 } & $\begin{array}{c}\text { Net Gen } \\
\text { (GWh) }\end{array}$ & 10,977 & 63,674 & 140,322 & 153,412 & 222,351 & 7,387 & 404,788 & 72,679 & 72.3 \\
\hline \multirow{4}{*}{$\begin{array}{c}\text { Coal } \\
\text { Frcen }\end{array}$} & Petroleum & 0.6 & 0.5 & 2.7 & 0.9 & 0.4 & 0.4 & 0.3 & 1.6 & 100.0 \\
\cline { 2 - 12 } & Gas & 30.9 & 32.6 & 31.3 & 1.6 & 8.4 & 97.4 & 47.7 & 12.8 & - \\
\cline { 2 - 11 } & Nuclear & 40.9 & 50.6 & 30.8 & 11.4 & 35.4 & - & 10.1 & 38.4 & - \\
\cline { 2 - 11 } & Hydro & 7.1 & - & 19.0 & 0.3 & 1.1 & 0.1 & 0.3 & 1.4 & - \\
\cline { 2 - 11 } & $\begin{array}{c}\text { Other } \\
\text { Renewables }\end{array}$ & 5.1 & 1.4 & 2.4 & 0.4 & 1.3 & 2.1 & 4.4 & 3.7 & - \\
\hline
\end{tabular}


Table 3a. Baseline Model Estimation Results ${ }^{6}$

\begin{tabular}{|c|c|c|c|c|c|c|c|}
\hline \multirow{2}{*}{$\begin{array}{l}\text { Baseline Model } \\
\text { Dependent Variable: Insarprice }\end{array}$} & \multirow{2}{*}{$\begin{array}{c}\text { Contemporaneous } \\
\text { Effect }\end{array}$} & \multicolumn{6}{|c|}{ Lagged Effects (Sum of lags) } \\
\hline & & $1-6$ & $1-5$ & $1-4$ & $1-3$ & $1-2$ & Lag 1 \\
\hline \multirow{2}{*}{ Insarprice } & - & - & - & - & - & - & 0.1158 \\
\hline & - & - & - & - & - & - & $(0.0730)$ \\
\hline \multirow{2}{*}{ participation } & $0.2959^{* *}$ & $-0.4480 * *$ & -0.0275 & $-0.2254 * *$ & -0.2287 & 0.0260 & -0.0472 \\
\hline & $(0.1142)$ & $(0.1874)$ & $(0.0803)$ & $(0.1000)$ & $(0.2049)$ & $(0.1012)$ & (0.1294) \\
\hline \multirow{2}{*}{ Intotalsalesmwh } & $-0.1255^{*}$ & 0.0777 & 0.0507 & 0.0474 & 0.0266 & 0.0268 & 0.0377 \\
\hline & $(0.0648)$ & $(0.1102)$ & $(0.1029)$ & $(0.0914)$ & $(0.0633)$ & $(0.0366)$ & $(0.0325)$ \\
\hline \multirow{2}{*}{ Incoalpriceelecgen } & -0.0027 & $0.2930 * * *$ & $0.2562 * * *$ & $0.3083^{* * *}$ & $0.3124 * *$ & $0.1434 * *$ & $0.2101 * * *$ \\
\hline & $(0.0934)$ & $(0.0723)$ & $(0.0968)$ & $(0.1170)$ & $(0.1224)$ & $(0.0613)$ & $(0.0511)$ \\
\hline \multirow{2}{*}{ lngaspriceelecgen } & -0.0102 & 0.0154 & 0.0145 & 0.0111 & -0.0039 & $0.0207^{* *}$ & -0.0051 \\
\hline & $(0.0081)$ & $(0.0167)$ & $(0.0138)$ & $(0.0112)$ & $(0.0098)$ & $(0.0084)$ & $(0.0071)$ \\
\hline \multirow{2}{*}{ penthydro } & 0.0057 & 0.0051 & -0.0061 & -0.0015 & $-0.0340 * * *$ & $-0.0298 * * *$ & 0.0011 \\
\hline & $(0.0140)$ & $(0.0355)$ & $(0.0195)$ & $(0.0239)$ & $(0.0104)$ & $(0.0106)$ & $(0.0095)$ \\
\hline \multirow{2}{*}{ pcntnuclear } & -0.0056 & 0.0069 & 0.0059 & 0.0099 & 0.0067 & 0.0039 & 0.0043 \\
\hline & $(0.0096)$ & $(0.0251)$ & $(0.0195)$ & $(0.0169)$ & $(0.0107)$ & $(0.0090)$ & $(0.0067)$ \\
\hline \multirow{2}{*}{ cddev } & 0.000020 & -0.000058 & -0.000007 & -0.000018 & 0.000005 & 0.000020 & 0.000014 \\
\hline & $(0.000034)$ & $(0.000118)$ & $(0.000105)$ & $(0.000081)$ & $(0.000057)$ & $(0.000029)$ & $(0.000033)$ \\
\hline \multirow{2}{*}{ hddev } & -0.00002 & -0.000019 & -0.000012 & -0.000013 & -0.000027 & -0.000026 & -0.000016 \\
\hline & $(0.00001)$ & $(0.000045)$ & $(0.000039)$ & $(0.000031)$ & $(0.000027)$ & $(0.000018)$ & $(0.000015)$ \\
\hline $\begin{array}{l}\text { Wald chi-square (80 d.f.): } \\
\qquad 547.72\end{array}$ & $\begin{array}{c}\text { Prob > Chi2 } \\
0.000\end{array}$ & $\begin{array}{l}\text { Arellano-Bond test } \\
\text { for AR(2) in first } \\
\text { differences: } \\
\mathrm{z}=1.34\end{array}$ & $\begin{array}{l}\text { Prob }>\text { z } \\
0.180\end{array}$ & \multicolumn{3}{|c|}{$\begin{array}{l}\text { Sargan test of overidentifying restrictions: } \\
\qquad \text { Chi2 } 2(1)=1.02\end{array}$} & $\begin{array}{c}\text { Prob > Chi2 } \\
0.313\end{array}$ \\
\hline
\end{tabular}

*** significant at $1 \% ; * *$ significant at $5 \% ; *$ significant at $10 \%$

Values in parentheses below coefficients are robust standard errors.

${ }^{6}$ Coefficients for PARTICIPATION, PCNTHYDRO, and PCNTNUCLEAR have been multiplied by 100 to allow for an interpretation analogous to the logged variables. For example, the results for the sum of lags 1-6 of the PARTICPATION variable should be read "a 1 percent increase in PARTICIPATION results in a -0.4557 percent decrease in the dependent variable". 
Table 3b. Baseline Model Estimation Results: Continued

\begin{tabular}{|c|c|}
\hline $\begin{array}{l}\text { Baseline Model } \\
\text { Dependent Variable: Insarprice }\end{array}$ & $\begin{array}{c}\text { Contemporaneous } \\
\text { Effect } \\
\end{array}$ \\
\hline \multirow{2}{*}{ retailcomp (TX) } & $-0.0034 * * *$ \\
\hline & $(0.0011)$ \\
\hline \multirow{2}{*}{ retailcomp +CAretailcomp } & $0.0173 * * *$ \\
\hline & $(0.0034)$ \\
\hline \multirow{2}{*}{ retailcomp + CTretailcomp } & $-0.0028 *$ \\
\hline & $(0.0015)$ \\
\hline \multirow{2}{*}{ retailcomp +DEretailcomp } & $0.0185^{* * *}$ \\
\hline & $(0.0042)$ \\
\hline \multirow{2}{*}{ retailcomp +ILretailcomp } & $0.0034 * * *$ \\
\hline & $(0.0003)$ \\
\hline \multirow{2}{*}{ retailcomp +MEretailcomp } & $-0.0029 * * *$ \\
\hline & $(0.0004)$ \\
\hline \multirow{2}{*}{ retailcomp +MDretailcomp } & $0.0058 * * *$ \\
\hline & $(0.0008)$ \\
\hline \multirow{2}{*}{ retailcomp +MAretailcomp } & 0.0002 \\
\hline & $(0.0007)$ \\
\hline \multirow{2}{*}{ retailcomp + MIretailcomp } & $0.0040 * * *$ \\
\hline & $(0.0005)$ \\
\hline \multirow{2}{*}{ retailcomp + NJretailcomp } & $0.0013 * *$ \\
\hline & $(0.0005)$ \\
\hline \multirow{2}{*}{ retailcomp $+\mathrm{NY}$ retailcomp } & 0.0002 \\
\hline & $(0.0006)$ \\
\hline \multirow{2}{*}{ retailcomp + PAretailcomp } & $-0.0087 * * *$ \\
\hline & $(0.0009)$ \\
\hline \multirow{2}{*}{ retailcomp +DCretailcomp } & $0.0043 * * *$ \\
\hline & $(0.0006)$ \\
\hline
\end{tabular}

*** significant at $1 \% ; * *$ significant at $5 \%$;

$*$ significant at $10 \%$

Values in parentheses below coefficients are robust standard errors.

\begin{tabular}{|c|c|}
\hline $\begin{array}{l}\text { Baseline Model } \\
\text { Dependent Variable: Insarprice }\end{array}$ & $\begin{array}{c}\text { Contemporaneous } \\
\text { Effect } \\
\end{array}$ \\
\hline ratecap (TX) & $\begin{array}{c}0.0087 * * * \\
(0.0011)\end{array}$ \\
\hline ratecap + CAratecap & $\begin{array}{c}-0.0155 * * * \\
(0.0037)\end{array}$ \\
\hline ratecap +DEratecap & $\begin{array}{c}-0.0164 * * * \\
(0.0044)\end{array}$ \\
\hline ratecap + ILratecap & $\begin{array}{c}-0.0063 * * * \\
(0.0006)\end{array}$ \\
\hline ratecap +MDratecap & $\begin{array}{c}-0.0070 * * * \\
(0.0011)\end{array}$ \\
\hline ratecap +MAratecap & $\begin{array}{c}0.0002 \\
(0.0007)\end{array}$ \\
\hline ratecap + MIratecap & $\begin{array}{c}-0.0056 * * * \\
(0.0009)\end{array}$ \\
\hline ratecap $+N Y$ ratecap & $\begin{array}{c}-0.0073 * * * \\
(0.0014)\end{array}$ \\
\hline ratecap +RIratecap & $\begin{array}{c}-0.0169 * * * \\
(0.0026)\end{array}$ \\
\hline ratecap + DCratecap & $\begin{array}{c}-0.0022 * * * \\
(0.0007) \\
\end{array}$ \\
\hline \multicolumn{2}{|c|}{$\begin{array}{l}* * * \text { significant at } 1 \% ; * * \text { significant at } 5 \% \\
* \text { significant at } 10 \% \\
\text { Values in parentheses below coefficients are robust } \\
\text { standard errors. }\end{array}$} \\
\hline
\end{tabular}


Table 4a. Estimation Results with Year Time Dummies Included

\begin{tabular}{|c|c|c|c|c|c|c|c|}
\hline \multirow{2}{*}{$\begin{array}{l}\text { Baseline Model } \\
\text { w/ Time Dummies } \\
\text { Dependent Variable: Insarprice }\end{array}$} & \multirow{2}{*}{$\begin{array}{l}\text { Contemporaneous } \\
\text { Effect }\end{array}$} & \multicolumn{6}{|c|}{ Lagged Effects (Sum of lags) } \\
\hline & & $1-6$ & $1-5$ & $1-4$ & $1-3$ & $1-2$ & $\operatorname{Lag} 1$ \\
\hline \multirow{2}{*}{ Insarprice } & - & - & - & - & - & - & $0.1284 *$ \\
\hline & - & - & - & - & - & - & $(0.0699)$ \\
\hline \multirow{2}{*}{ participation } & $0.3216 * * *$ & $-0.3803 * * *$ & 0.0232 & $-0.1760 *$ & -0.2005 & 0.0428 & -0.0357 \\
\hline & $(0.0916)$ & $(0.1406)$ & $(0.1192)$ & $(0.0912)$ & $(0.1794)$ & $(0.1075)$ & $(0.1440)$ \\
\hline \multirow{2}{*}{ lntotalsalesmwh } & $-0.1280 * *$ & 0.0634 & 0.0375 & 0.0364 & 0.0173 & 0.0203 & 0.0353 \\
\hline & $(0.0651)$ & $(0.1162)$ & $(0.1091)$ & $(0.0962)$ & $(0.0661)$ & $(0.0368)$ & $(0.0314)$ \\
\hline \multirow{2}{*}{ Incoalpriceelecgen } & 0.0375 & $0.4736 * * *$ & $0.3768 * *$ & $0.3973 * * *$ & $0.3752 * * *$ & $0.1852 * * *$ & $0.2312 * * *$ \\
\hline & $(0.1024)$ & $(0.1500)$ & $(0.1495)$ & $(0.1269)$ & $(0.1286)$ & $(0.0672)$ & $(0.0520)$ \\
\hline \multirow{2}{*}{ Ingaspriceelecgen } & -0.0042 & 0.0191 & 0.0215 & 0.0166 & 0.0015 & $0.0245^{* * *}$ & -0.0039 \\
\hline & $(0.0082)$ & $(0.0158)$ & $(0.0136)$ & $(0.0105)$ & $(0.0081)$ & $(0.0085)$ & $(0.0069)$ \\
\hline \multirow{2}{*}{ penthydro } & 0.0056 & 0.0061 & -0.0051 & -0.0009 & $-0.0333 * * *$ & $-0.0298 * * *$ & 0.0003 \\
\hline & $(0.0139)$ & $(0.0370)$ & $(0.0211)$ & $(0.0248)$ & $(0.0117)$ & $(0.0113)$ & $(0.0098)$ \\
\hline \multirow{2}{*}{ pcntnuclear } & -0.0051 & 0.0089 & 0.0076 & 0.0112 & 0.0077 & 0.0046 & 0.0046 \\
\hline & $(0.0095)$ & $(0.0254)$ & $(0.0197)$ & $(0.0173)$ & $(0.0113)$ & $(0.0093)$ & $(0.0070)$ \\
\hline \multirow{2}{*}{ cddev } & 0.000019 & -0.000043 & 0.000006 & -0.000008 & 0.000013 & 0.000026 & 0.000016 \\
\hline & $(0.000033)$ & $(0.000128)$ & $(0.000114)$ & $(0.000090)$ & $(0.000065)$ & $(0.000033)$ & $(0.000033)$ \\
\hline \multirow{2}{*}{ hddev } & $-0.000022^{*}$ & -0.000033 & -0.000023 & -0.000022 & -0.000035 & $-0.000031 *$ & -0.000020 \\
\hline & $(0.000013)$ & $(0.000048)$ & $(0.000042)$ & $(0.000033)$ & $(0.000028)$ & $(0.000018)$ & $(0.000015)$ \\
\hline $\begin{array}{l}\text { Wald chi-square (100 d.f.): } \\
\qquad 401.35\end{array}$ & $\begin{array}{c}\text { Prob }>\text { Chi2 } \\
0.000\end{array}$ & $\begin{array}{l}\text { Arellano-Bond test } \\
\text { for } A R(2) \text { in first } \\
\text { differences: } \\
z=1.59\end{array}$ & $\begin{array}{c}\text { Prob > z } \\
0.111\end{array}$ & \multicolumn{3}{|c|}{$\begin{array}{l}\text { Sargan test of overidentifying restrictions: } \\
\qquad \text { Chi } 2(1)=1.43\end{array}$} & $\begin{array}{c}\text { Prob }>\text { Chi2 } \\
0.231\end{array}$ \\
\hline
\end{tabular}

*** significant at $1 \% ; * *$ significant at $5 \% ; *$ significant at $10 \%$

Values in parentheses below coefficients are robust standard errors. 
Table 4b. Estimation Results with Year Time Dummies Included: Continued

\begin{tabular}{|c|c|}
\hline \begin{tabular}{|l} 
Baseline Model \\
w/ Time Dummies \\
Dependent Variable: Insarprice
\end{tabular} & $\begin{array}{c}\text { Contemporaneous } \\
\text { Effect }\end{array}$ \\
\hline \multirow{2}{*}{ retailcomp (TX) } & $-0.0042 * *$ \\
\hline & $(0.0018)$ \\
\hline \multirow{2}{*}{ retailcomp +CAretailcomp } & $0.0185^{* * *}$ \\
\hline & $(0.0035)$ \\
\hline \multirow{2}{*}{ retailcomp + CTretailcomp } & $-0.0031 *$ \\
\hline & $(0.0017)$ \\
\hline \multirow{2}{*}{ retailcomp + DEretailcomp } & $0.0161 * * *$ \\
\hline & $(0.0047)$ \\
\hline \multirow{2}{*}{ retailcomp +ILretailcomp } & $0.0024^{*}$ \\
\hline & $(0.0014)$ \\
\hline \multirow{2}{*}{ retailcomp +MEretailcomp } & $-0.0034 * *$ \\
\hline & $(0.0013)$ \\
\hline \multirow{2}{*}{ retailcomp +MDretailcomp } & $0.0043^{* *}$ \\
\hline & $(0.0020)$ \\
\hline \multirow{2}{*}{ retailcomp + MAretailcomp } & -0.0013 \\
\hline & $(0.0014)$ \\
\hline \multirow{2}{*}{ retailcomp +MIretailcomp } & 0.0022 \\
\hline & 0.0019 \\
\hline \multirow{2}{*}{ retailcomp + NJretailcomp } & 0.0018 \\
\hline & $(0.0014)$ \\
\hline \multirow{2}{*}{ retailcomp $+\mathrm{NY}$ retailcomp } & -0.0011 \\
\hline & $(0.0017)$ \\
\hline \multirow{2}{*}{ retailcomp +PAretailcomp } & $-0.0078 * * *$ \\
\hline & $(0.0016)$ \\
\hline \multirow{2}{*}{ retailcomp + DCretailcomp } & $0.0037 * *$ \\
\hline & $(0.0016)$ \\
\hline
\end{tabular}

$* * *$ significant at $1 \% ; * *$ significant at $5 \%$;

* significant at $10 \%$

Values in parentheses below coefficients are robust standard errors.

\begin{tabular}{|c|c|}
\hline \begin{tabular}{|l} 
Baseline Model \\
w/ Time Dummies \\
Dependent Variable: Insarprice
\end{tabular} & $\begin{array}{c}\text { Contemporaneous } \\
\text { Effect }\end{array}$ \\
\hline \multirow{2}{*}{ ratecap (TX) } & $0.0074 * * *$ \\
\hline & $(0.0008)$ \\
\hline \multirow{2}{*}{ ratecap + CAratecap } & $-0.0163 * * *$ \\
\hline & $(0.0033)$ \\
\hline \multirow{2}{*}{ ratecap +DEratecap } & $-0.0138 * * *$ \\
\hline & $(0.0045)$ \\
\hline \multirow{2}{*}{ ratecap + ILratecap } & $-0.0057 * * *$ \\
\hline & $(0.0008)$ \\
\hline \multirow{2}{*}{ ratecap +MDratecap } & $-0.0053 * * *$ \\
\hline & $(0.0017)$ \\
\hline \multirow{2}{*}{ ratecap +MAratecap } & $0.0028 * * *$ \\
\hline & $(0.0009)$ \\
\hline \multirow{2}{*}{ ratecap+MIratecap } & $-0.0031 *$ \\
\hline & $(0.0017)$ \\
\hline \multirow{2}{*}{ ratecap $+\mathrm{NY}$ ratecap } & $-0.0044 * *$ \\
\hline & $(0.0021)$ \\
\hline \multirow{2}{*}{ ratecap + RIratecap } & $-0.0145^{* * *}$ \\
\hline & $(0.0025)$ \\
\hline \multirow{2}{*}{ ratecap +DCratecap } & $-0.0023 * *$ \\
\hline & $(0.0010)$ \\
\hline
\end{tabular}

*** significant at $1 \%$; ** significant at $5 \%$;

* significant at $10 \%$

Values in parentheses below coefficients are robust standard errors. 
Table 4c. Estimation Results with Year Time Dummies Included: Time Dummies

\begin{tabular}{|c|c|c|c|}
\hline Time Dummies & $\begin{array}{c}\text { Contemporaneous } \\
\text { Effect }\end{array}$ & Time Dummies & $\begin{array}{c}\text { Contemporaneous } \\
\text { Effect }\end{array}$ \\
\hline \multirow{2}{*}{1991} & $0.0044 * * *$ & \multirow{2}{*}{2001} & -0.0004 \\
\hline & $(0.0010)$ & & $(0.0025)$ \\
\hline \multirow{2}{*}{1992} & 0.0008 & \multirow{2}{*}{2002} & -0.0014 \\
\hline & $(0.0010)$ & & $(0.0013)$ \\
\hline \multirow{2}{*}{1993} & $0.0021 *$ & \multirow{2}{*}{2003} & -0.0009 \\
\hline & $(0.0011)$ & & $(0.0018)$ \\
\hline \multirow{2}{*}{1994} & $0.0018 * *$ & \multirow{2}{*}{2004} & -0.0029 \\
\hline & $(0.0008)$ & & $(0.0021)$ \\
\hline \multirow{2}{*}{1995} & 0.0020 & \multirow{2}{*}{2005} & -0.0011 \\
\hline & $(0.0013)$ & & $(0.0032)$ \\
\hline \multirow{2}{*}{1996} & -0.0001 & \multirow{2}{*}{2006} & 0.0050 \\
\hline & $(0.0011)$ & & $(0.0036)$ \\
\hline \multirow{2}{*}{1997} & $-0.0023 *$ & \multirow{2}{*}{2007} & 0.0040 \\
\hline & $(0.0012)$ & & $(0.0030)$ \\
\hline \multirow{2}{*}{1998} & -0.0023 & \multirow{2}{*}{2008} & -0.0027 \\
\hline & $(0.0012)$ & & 0.0039 \\
\hline \multirow{2}{*}{1999} & -0.0012 & \multirow{2}{*}{2009} & -0.0022 \\
\hline & $(0.0018)$ & & $(0.0017)$ \\
\hline \multirow{2}{*}{2000} & 0.0015 & \multirow{2}{*}{2010} & -0.0016 \\
\hline & $(0.0016)$ & & $(0.0026)$ \\
\hline
\end{tabular}

$* * *$ significant at $1 \% ; * *$ significant at $5 \% ; *$ significant at $10 \%$

Values in parentheses below coefficients are robust standard errors. 


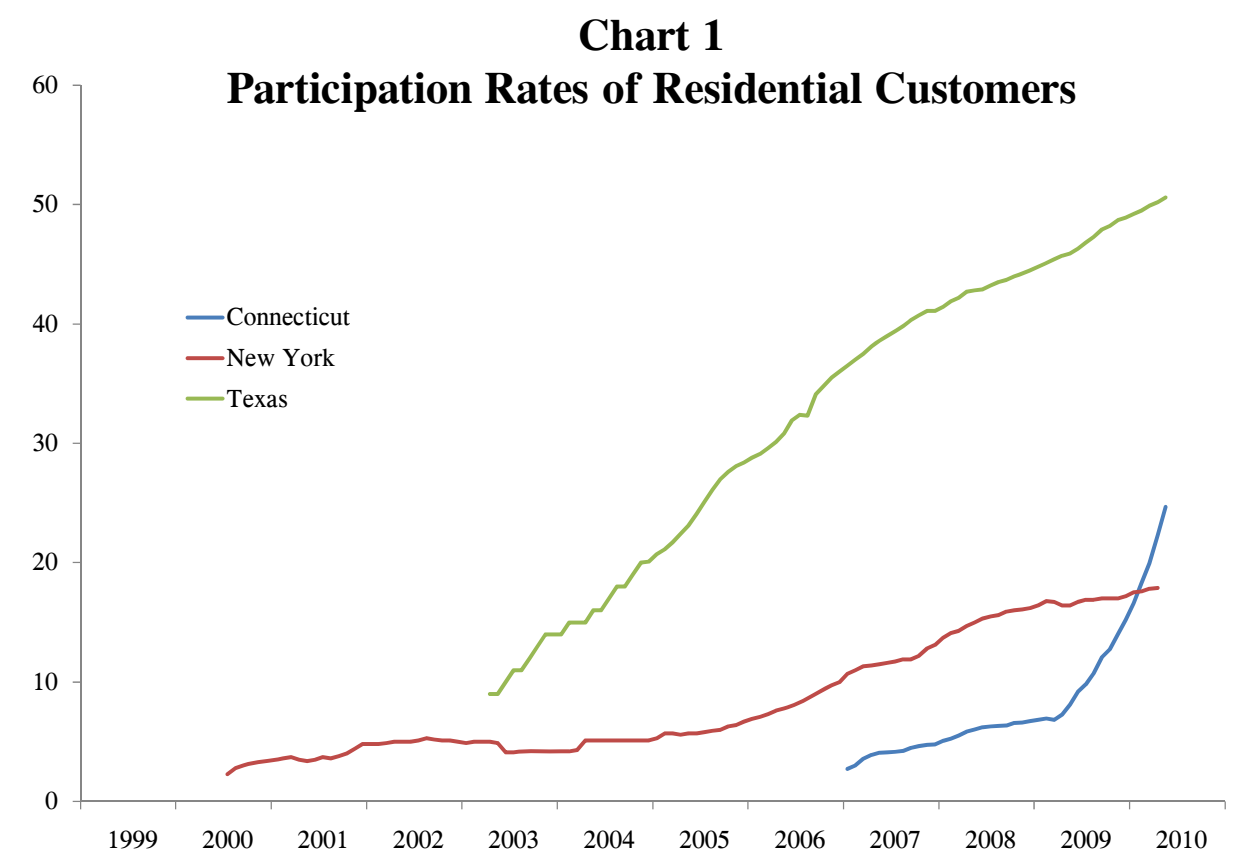

Chart 2

Fuel Prices and Average Residential Electricity Rates

SA, Real, July $2010 \$$

$\$ / \mathrm{mmbtu}$ (coal and gas)

Cents/KwH (electricity)

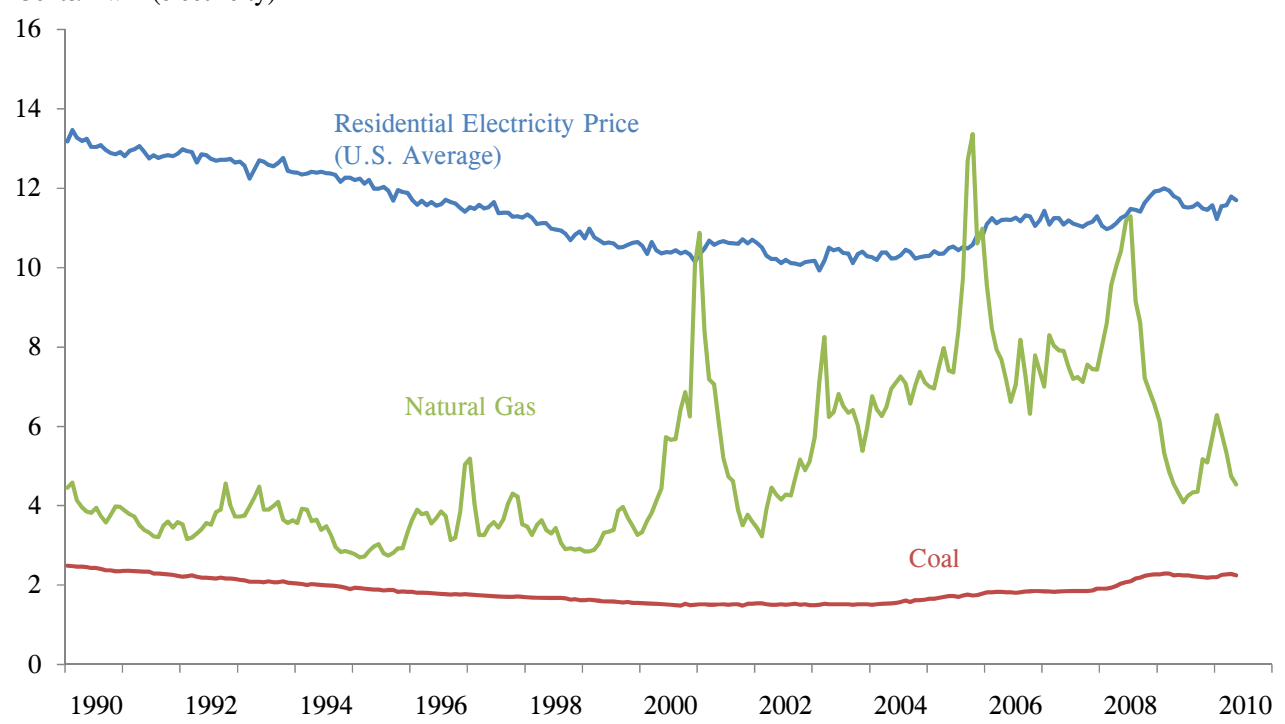




\section{References}

Adib, P., Zarnikau, J., 2006. Texas: the most robust competitive market in North America. In: Sioshansi, F.P., Pfaffenberger, W. (Eds.), Electricity Market Reform: An International Perspective. Elsevier, New York.

Anderson, T. W., Hsiao, C., 1982. Formulation and Estimation of Dynamic Models Using Panel Data. Journal of Econometrics 18, 47-82.

Apt, J., 2005. Competition has not Lowered U.S. Industrial Electricity Prices. The Electricity Journal 18(2), 52-61.

Arellano, M., 1989. A Note on the Anderson-Hsiao Estimator for Panel Data. Economics Letters 31, 337-341.

Arellano, M., Bond, S., 1991. Some Tests of Specification for Panel Data: Monte Carlo Evidence and an Application to Employment Equations. The Review of Economic Studies 58, 277-297.

Axelrod, H., DeRamus, D., Cain, C., 2006. The fallacy of high prices. Public Utilities Fortnightly 144(11), 55-60.

Bushnell, J., Mansur, E., 2005. Consumption under noisy price signals: A study of electricity retail rate regulation in San Diego. The Journal of Industrial Economics 53(4), 493-513.

Cameron, A.C., Trivedi, P.K., 2010. Microeconometrics Using Stata: Revised Edition. Stata Press, College Station.

Holtz-Eakin, D., Newey,W., Rosen, H.S., 1988. Estimating Vector Autoregressions with Panel Data. Econometrica 56, 1371-1395.

Joskow, P.L., 2006. Markets for power in the United States: an interim assessment. The Energy Journal 27(1), 1-36.

Judson, R.A., Owen, A.L., 1999. Estimating dynamic panel models: A practical guide for macroeconomists. Economics Letters 65, 9-15.

Kang, L., Zarnikau, J., 2009. Did the expiration of retail price caps affect prices in the restructured Texas electricity market? Energy Policy 37, 1713-1717.

Kiviet, J.F., 1995. On bias, inconsistency, and efficiency of various estimators in dynamic panel data models. Journal of Econometrics 68, 53-78.

Nickell, S., 1981. Biases in Dynamic Models with Fixed Effects. Econometrica 49, 14171426. 
Roe, B., Teisl, M., Levy, A., Russel, M. 2001. U.S. consumers' willingness to pay for green electricity. Energy Policy 29, 917-925.

Roodman, D., 2006. How to do Xtabond2: An Introduction to Difference and System GMM in Stata. Working paper 103. Center for Global Development, Washington, DC.

-., 2009. A Note on the Theme of Too Many Instruments. Oxford Bulletin of Economics and Statistics 71, 135-158.

Rose, K., 2004. The State of Retail Electricity Markets in the U.S. The Electricity Journal $17(1), 26-36$.

U.S. Energy Information Administration (EIA), 2007. Legislation and Regulations:

Electricity Prices in Transition. Annual Energy Outlook 2007 with Projections to 2030, DOE/EIA-0383. pp.25-28. U.S. Department of Energy, Washington, DC.

Zarnikau, J., Adib P., 2007. Will the Texas Market Succeed, Where So Many Others Have Now Failed? Frontier Associates LLC. Proceedings of the $28^{\text {th }}$ Annual USAEE/IAEE North American Conference, December 2008, New Orleans, LA.

Zarnikau, J., Whitworth D., 2006. Has Electric Utility Restructuring Led to Lower Electricity Prices for Residential Consumers in Texas? Energy Policy 34(15), 2191 2200. 